\section{New hopes, old doubts}

Loren Graham

Man, Sclence, Humanism: A New Synthesis. By Ivan Frolov. Prometheus: 1991. Pp.342. £15.95, \$24.95.

Ivan Frolov, a leading philosopher in the Soviet Union and currently the editor of Pravda, has had a career that symbolizes both the new hopes and the old doubts about that country held by much of the rest of the world. Just as is the case with Gorbachev, Frolov rose to prominence on an anti-establishment reform platform. And just as with Gorbachev, he has now passed into a phase in which his work appears to be preserving the remnants of the old order more than continuing to push for a new one. But in the interim, Frolov, like Gorbachev, has helped to change the Soviet Union irretrievably. The story is a dramatic and complex one.

Frolov's main interests have always been the philosophy and ethics of science. In the 1960 s he first came to the attention of intellectuals in the Soviet Union by writing a book in which he opposed the views of the pseudoscientist Trofim Lysenko, who still exercised great influence in Soviet biology. Frolov was a marxist, then and now, but he maintained that nothing in marxism required the denial of genetics.

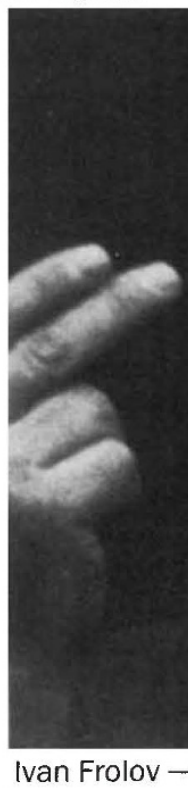
Indeed, Frolov observed that it was immensely ironic, and tragic, that the chromosome theory of inheritance, postulating the existence of material carriers of heredity, should be opposed by many Soviet marxists in the name of philosophical materialism.

Identified by this early work as a new and bold spirit among Soviet philosophers, Frolov went on to become the editor of the main philosophy journal in the Soviet Union, and there he set about refreshing Soviet philosophy of science by establishing closer ties with the natural scientists. At the same time, he became more and more interested in 'global' problems such as pollution of the environment, the shortage of energy resources, and biomedical ethics. The study of such problems was viewed by the old-fashioned ideologists as unorthodox; the dogmatists criticized the assumption made by most 'globalists' like Frolov that the problems of industrialized nations transcend class and economic rivalries to such a degree that the capitalist and socialist nations should overcome their traditional rivalries and work together.

With the decline of détente in the late
1970 s, the militant ideologists opposed to Frolov's accommodationist views gained in influence. Frolov lost his job as editor of the main philosophy journal and was replaced by a much more orthodox thinker. Unable to continue his reforming efforts, Frolov turned more and more to studies of biomedical ethics, of which Man, Science, Humanism: A New Synthesis is one product. He is particularly interested in the morality of eugenics and genetic engineering applied to humans.

Frolov observes that Marxism is based on a relativistic vision of the history of civilization in which moral standards evolve in step with the development of material culture. Therefore, the possibility of the conscious and widespread application of genetic engineering to human beings in the future (even in ways that seem morally offensive now) can- such as in vitro fertilization, the cessation of care to newly born deformed infants and terminally ill patients, the freezing of human embryos, the mapping of the human genome, the rules governing fetal research, the advisability of gene therapy, and the priorities among patients in receiving organ transplants. Frolov's highly abstract formulations, although on one level commendable, are not very helpful to working scientists and physicians facing these questions.

Frolov accepted Gorbachev's request that he become editor of Pravda, the main Communist Party newspaper, shortly before Gorbachev began to move in a more conservation direction. As a result, Frolov, who once was the main reforming spirit in Soviet philosophy, now must justify in his newspaper all the retrogressive steps recently taken by the Soviet government: the violent repression of the Lithuanians last January,
the tightening of control over

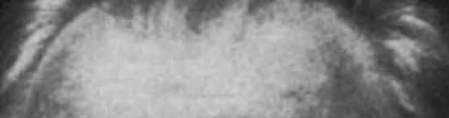
Soviet television, the new restrictions on a free economy, and the effort to hold the Soviet Union together at all costs. Irritated by these editorial policies, and attracted by publications of the new independent groups in the Soviet Union, the Soviet reading public has massively turned away from Pravda. Its circulation is plummeting.

Even in this book Frolov seems more traditional than he earlier did. He warns that global problems should not be viewed outside the 'contradiction' between declining capitalism and victorious socialism; he praises the now defunct Council of Mutual Economic since his editorship, Pravda has changed significantly. Assistance (the economic asso-
not be excluded. On the other hand, main- $\mid$ ciation of the East European states); he tains Frolov, it would be a great mistake to make such an effort now. For the time being, all eugenic ideas and all proposals to engineer a better human species should be rejected. The reasons, he says, are twofold: the science of genetics is still too incomplete and, even more important, power in the world is too unequally distributed. At some far future date, however, the question of improving the human species should be raised again; we should leave it to the people of that time, says Frolov, to decide the question, relying on what is anticipated to be their much better science of genetics within what will be, hopefully, a more just society.

Frolov's position contains a great deal of common sense. He avoids both the dangers posed by enthusiastic neo-eugenicists and those presented by fundamentalists who oppose all tampering with human genetics. But the weakness of Frolov's stand is its limited use in handling pressing practical questions. Frolov postpones the hard bioethical questions to the far future at a moment when all over the world physicians and researchers are already making decisions on questions maintains that only in socialist and communist societies can new technologies be placed in the service of humankind.

Those of us who remember when Frolov fought for diversity and unorthodoxy in Soviet philosophy are sorry to see this conservative turn. Of course, even now all is not lost. Frolov is a true follower of Gorbachev, and like his leader, he has opponents on his right as well as on his left; both of them are far more enlightened than their possible rightwing replacements. Furthermore, in a journal which Frolov founded entitled Chelovek ('The Human Being'), many of his earlier ideas continue to appear.

Frolov's strength has not been moving from philosophical principles to practical action, as this book illustrates. Hence, no surprise that he is better at editing philosophy journals, or writing philosophical tracts, than at editing daily newspapers.

Loren Graham is at the Massachusetts Institute of Technology, Program in Science, Technology, and Society, Cambridge, Massachusetts 02139, USA. 